\title{
The Children Rights Protection in the New Normal Era: an Indonesia Experience during Covid-19 Pandemic
}

\author{
Izza Aliyatul Millah ${ }^{1 *}$, Pujiyono ${ }^{2}$
}

${ }^{1,2}$ Faculty of Law, Diponegoro University, Semarang, Central Java, 50275, Indonesia

*Corresponding author: izzaaliyatulmillah@yahoo.com

\begin{tabular}{|c|c|}
\hline Article & Abstract \\
\hline $\begin{array}{l}\text { Article History } \\
\text { Received: July 26, 2020; } \\
\text { Reviewed: July 28, 2020; } \\
\text { Accepted: Sept 22, 2020; } \\
\text { Published: Sept 30, } 2020\end{array}$ & $\begin{array}{l}\text { The new normal era is a necessity and must be faced by all countries until the } \\
\text { discovery of the Covid-19 disease vaccine. The implementation of this new normal } \\
\text { era policy has caused public debate related to various concerns of the people, } \\
\text { especially the state's readiness to guarantee the safety of the population from the } \\
\text { transmission of Covid-19, especially in the protection of children in terms of } \\
\text { fulfilling their rights. This paper aims to find out child protection providers in } \\
\text { providing protection and fulfillment of children's rights in new normal behavior } \\
\text { during the Covid-19 pandemic and to find out the implementation of policies } \\
\text { towards the protection of children's rights in new normal behavior during the Covid- } \\
19 \text { pandemic. This research uses doctrinal law research. Legal information sources } \\
\text { use primary legal materials (relevant regulations and documents) for further } \\
\text { qualitative analysis. The approach used is a statutory approach and conceptual } \\
\text { approach in helping solving problem formulations. This research concludes that the } \\
\text { right effort to deal with the new normal era is to strengthen child protection based } \\
\text { on children's rights, starting from parents, family, community, and government } \\
\text { during the pandemic. Associated with the establishment of a policy schedule for } \\
\text { children entering school when the new normal era in the Covid-19 pandemic. The } \\
\text { key to protecting children in the new normal era is the health protocol rules that } \\
\text { can be a guideline for parents and caregivers of children and the fulfillment of } \\
\text { children's primary rights in the new normal era is the health and safety aspects of } \\
\text { children. }\end{array}$ \\
\hline \multicolumn{2}{|c|}{$\begin{array}{l}\text { (C)2020; This is an Open Acces Research distributed under the term of the Creative Commons } \\
\text { Attribution Licencee (https://Creativecommons.org/licences/by/4.0), which permits unrestricted } \\
\text { use, distribution, and reproduction in any medium, provided the original works is properly cited. }\end{array}$} \\
\hline
\end{tabular}

\section{INTRODUCTION}

Children are the potential and the younger generation to succeed in the ideals of the nation's struggle, have a strategic role and have special characteristics and traits that guarantee the continued existence of the nation and state in the future (Hidayati, 2014; Rihardi, 2018; Wati \& Puspitasari, 2018). Children's rights are part of human 
rights contained in the 1945 Constitution of the Republic of Indonesia and the United Nations Convention on the Rights of the Child. The provisions of Article 28B paragraph (2) of the Constitution of the Republic of Indonesia state that every child has the right to survival, growth, and development and is entitled to protection from violence and discrimination.

The Convention on the Rights of the Child specifically regulates everything concerning children's rights. The Convention on the Rights of the Child began to take effect on September 2, 1990, through the United Nations revolution dated November 20, 1989, and in accordance with the provisions of the Article 49 paragraph (1) Convention. In this convention, the child is the holder of basic rights and freedoms as well as the party receiving special protection. The Convention on the Rights of the Child also arises from an awareness that children in accordance with their nature are vulnerable, weak, innocent, and have special needs. Therefore also children need special care and protection, both physical and mental.

Indonesia in ensuring the welfare of every citizen is one of them by providing protection for the rights of children which is one of the human rights (Juliana \& Arifin, 2019; Lasmadi et al., 2020). The Government of Indonesia in its efforts to guarantee and realize child protection and welfare is through the establishment of Law Number 23 of 2002 concerning Child Protection. In the context of adjustments to several provisions, a number of changes were made to certain articles, thus enacting Law Number 35 of 2014 concerning changes to Law Number 23 of 2002 concerning Child Protection (Child Protection Law).

The problem of providing protection for children, in welcoming a new normal era or widely known as "New normal" is a necessity and must be faced by all countries until the discovery of a vaccine for Covid-19 disease (Disemadi \& Shaleh, 2020). In the last few days, the implementation of this new normal policy has caused public debate related to various concerns of the people, especially the state's readiness to guarantee the safety of the population from the transmission of Covid-19 (Fitriyana, 2020; Muhyiddin, 2020), especially in the protection of children in terms of fulfilling their rights. Protection of the child during the implementation of the new normal is all activities to guarantee and protect children and their rights so that they can live, grow, develop, and participate optimally in accordance with human dignity and dignity, and get protection from violence and discrimination.

Deputy for Child Protection at the Indonesia Ministry of Women's Empowerment and Child Protection Nahar said, based on data from the National Task Force (Gugus Tugas Nasional) as of June 2, the percentage of children aged 6 to 17 years of the total people who indicated positive Covid-19 was 5.6 percent (Saputra, 2020). This is proof that children are also threatened in this pandemic situation, so it needs to be a common concern. Therefore, a new normal policy strategy is needed to be accompanied by a variety of new normal protocols that can be implemented precisely and consistently with due regard to the best interests of the child. 
Child protection is closely related to the five pillars namely, parents, family, community, government, regional, and state government (Azkia \& Is, 2018; Fitriani, 2016; Sudrajat, 2011). All five have links to one another as providers of child protection. In its simplest form, child protection strives so that every child's right is not harmed. Child protection is complementary to other rights ensuring that children will receive what they need so they can survive, develop, and grow (Fitriani, 2016; Hidayati, 2014). The adoption of the new normal policy in the midst of the Covid-19 pandemic requires parents and families in Indonesia to provide care for children that are adapted to changing conditions today. Since children are the most vulnerable creatures, we must protect them and the role of care is very important.

Based on the background that has been described above, the focus of this research is, namely: 1). How do child protection providers provide protection and fulfillment of children's rights in new normal behavior amid the Covid-19 pandemic?; and 2). How is the implementation of the policy towards protecting children's rights in the new normal behavior amid the Covid-19 pandemic?. Therefore, the contribution of this research is to examine the protection of children's rights in the "New normal era" amid the Covid-19 pandemic in Indonesia. This research is important to do to support literacy to the public regarding the protection of children's rights in Indonesia.

\section{METHOD}

The research method used is a normative legal research method with descriptiveanalytical research specifications (Peter Mahmud Marzuki, 2014). This research includes literature studies so that this research emphasizes secondary data that is relevant to the topic raised namely the protection of children's rights in the "New normal era" amid the Covid-19 pandemic. The design of the study of literature studies is a series of activities to obtain secondary data such as primary, secondary, and tertiary legal material through literature study as a data collection technique, which is then read, recorded and analyzed qualitatively to get actual conclusions.

\section{RESULTS AND DISCUSSION}

\section{Child Protection in Indonesia}

Legal protection for children can be interpreted as a legal protection effort against fundamental rights and freedoms of children and various interests related to child welfare (Azkia \& Is, 2018; Setiawan et al., 2019). But in this case the problem of legal protection for children not only includes the protection of the law in the judicial process, but it covers everything on the child's freedom to obtain a proper treatment like other citizens (Said, 2018). The increasing atmosphere of violence and disharmony in the environment of everyday life in a city/region will put the children at a very high risk. Where he no longer feels safe playing with other children. Because indirectly resulted in the child's independence become deprived (A. M. Sirait, 2018; Sudrajat, 2011).

As such, the above, today has resulted in many children who commit crimes that concern the public even if the child to commit violations of criminal law. In this case, we need to know that the child's criminal liability system (including the giving of action) 
is essentially still the same as the adult accountability system which is oriented towards the perpetrator personally/individually (Setiawan et al., 2019; Sudrajat, 2011; Wahyuni, 2015). The application of this principle to the child still needs to be examined, because the child can not be said to be fully independent individual. Therefore, the application of this general principle should be done carefully and selectively, given that the level of maturity/maturity of each child is different (Purnamasari et al., 2019). Certainly the problem of children is more a structural problem. Moreover, because of the nature of Kekurangmandirian and dependence of the child, the child who commits mischief or crime is actually "Environmental victims", therefore the appropriate developed thinking/ideas/strategies of structural/functional accountability means that the pipetting not only serves to answer and nurture the child as a crime (Erdianti \& AlFatih, 2019). But it also serves to account for and to build (treatmen) the child as a perpetrator of criminals, but also serves to account for and foster/prevent other parties that are structural/functional have a big potential and contribution to the occurrence of crime/criminal offense committed by the child (Purnamasari et al., 2019).

Various international documents/instruments can also be seen as an international legal protection effort, although it is still a statement (declaration), a joint agreement (Convention), resolution or still a guideline (Hidayati, 2014; Istiqomah et al., 2019). The various international documents above are clearly a reflection of the international community's awareness and concern for the need for protection against the bad/depressing state of children around the world. From a variety of international documents and meetings, it is evident that the need for legal protection for children can cover various areas/aspects, including (Hariyadi \& Arliman S, 2018; Juliana \& Arifin, 2019): 1) Protection of the human rights and freedoms of children, 2) child protection in judicial proceedings, 3) child welfare protection (in the family environment, education and social environment). 4) Protection of children in the issue of independence detention and deprivation, 5) child protection of all forms of exploitation (slavery, child trafficking, prostitution, pornography, trade/abuse of drugs, enslaving children in committing crimes and so on, 6) protection against street children, 7) child protection from the consequences of war/armed conflict, and 8) child protection against violent acts So the issue of legal protection for children is not only legal protection in judicial proceedings, but covers a very broad spectrum.

The problems of "Working Children" are among the many children who become full-time child labour, child Trafficking (child prostitution), child bondage, child prostitution and child pornography caused by the increasing "Sex tourism" (children's) and children's pornography (Filler, 1995). The issue of "Street children" is estimated to be around the emergency of 150 million street children worldwide. The concern is, that in addition to their struggle to sustain material life, they are also subjected to abuse and exploitation (among others in "Street thieves, street prostitution, drug trade" and other organized crime activities). The concern also includes 'Alleys' among adolescents as a means for "Self-protection" in hostile environments (Filler, 1995). 
The problem of "Children in armed conflict" is revealed, that in an armed conflict situation in the last decade around 1.5 was also a murdered child, 4 million children with disabilities, 5 million children as refugees and 10 million children lost. Not to mention the victims of rape and suffer from psychiatric pressure (stress and trauma). The problem is quite difficult is to do coaching and reorientation them from the political situation/culture to the culture of peace. The problem "Urban war zones" (Filler, 1995). The problem expressed here is, that the atmosphere of violence and insecurity in the environment of everyday life in the city/region that becomes the "War zone" will put the children in "Very high risk". Especially when poverty, anesthetic and weapons use and crime are the reality of everyday life, the inhabitants of the city (especially children) are in danger and chronic tension (chronic danger and stress) (Filler, 1995).

The Issue "The instrumental use of children" this issue was disclosed in connection with the recommendation of the $8^{\text {th }}$ United Nation Congress of 1990 which later became United Nations resolution No. 45/115 years 1990 and a group meeting of experts in Rome, Italy on May 8-10, 1992. At an expert meeting in Rome it was presented, that one factor of the condition there was the practice of "Having children to commit crimes" was, the absence of special legislation for adults who exploited children (Filler, 1995).

The child is someone who is not yet 18 (eighteen) years old, including children who are still in the womb according to the contents of article 1 number (1) of the Law on Child Protection. Children are the offspring between father and mother through a legal marriage or not. Humans as living things develop and produce offspring that develop to form a family tree (Disemadi, 2019).

The sociological aspect of the understanding of children shows that children are social creatures created by God, which always interacts with the environment of the nation and state society (Arliman.S, 2016; Setyaningrum \& Arifin, 2019). In this case, children are positioned as the smallest social group in society. The meaning of children from this social aspect leads to natural protection because of the limitations possessed by children as a form of interaction with adults (Umar \& Ma'ani, 2018; Windari, 2019). The ability limitation factor is because the child is in the process of growth, the learning process, and the process of socialization due to the age of immature: due to the ability of reasoning (intellect) and physical conditions in growth or spiritual mental under the age group of adults (Anindia, 2019; Gosita, 1999).

In child development psychology it is widely discussed that the basis of a person's personality is formed in childhood. The developmental processes that occur in a child coupled with what is experienced and received during his childhood are gradually enabling him to grow and develop into an adult human (Azkia \& Is, 2018; Fitriani, 2016; Sholihah, 2018). With the growth of the child, then the child will continue to explore the extent to which their parents can tolerate their actions and this is what requires reassessment by parents. They also feel that they still have to test the firmness of their parents, to what extent their parents can still stand up to their 
behavior. Parents who had previously only behaved as friends, could not help but be confronted with such a problem. In the end these parents must be assertive, at least starting from that moment, or eventually they will lose their temper and become angry. Realities in society often process children carrying out economic activities or productivity activities that can produce economic values. Understanding groups of children in the economic field, leading to the conception of child welfare stipulated by Law No. 4 of 1979 concerning Child Welfare is "Children's basic rights must be pursued together". The child's view of religious understanding will be built according to religious teachings, the child gets a special position. Children are God's entrusted items to parents to be loved and educated (Sholihah, 2018). In our law there is pluralism regarding the understanding of children, this is a result of each of the laws and regulations that govern separately about the child's understanding.

Then, the meaning and definition of protection means the place of refuge or protect. Protection is a shelter from harmful actions. Protection exists to protect a thing because of the inability to protect oneself. As an example of child protection, children need to get protection from the government, family, community, and their parents during their growing years so that they do not get arbitrary treatment from irresponsible parties.

The definition of child protection based on the legal dictionary is all activities to guarantee and protect children and their rights so that they can live, grow, develop and participate optimally, following human dignity and dignity, and receive protection from violence and discrimination (Novika et al., 2020). Child protection is any effort aimed at preventing, rehabilitating and empowering children who experience acts of mistreatment, exploitation and neglect to ensure the survival and development of children naturally, physically, mentally and socially.

In essence, children cannot protect themselves against various kinds of mental, physical, social threats in various fields of life. Therefore children must be assisted by others in protecting themselves given the situation and conditions. Protecting children is protecting humans and developing a whole person. Child protection is very important for the creation of state continuity, because children are the forerunner of a generation of people in nation-building. Child protection is an attempt to establish conditions and situations that allow the implementation of positive human rights and obligations of children.

So, it can be said that child protection is a written and unwritten law that guarantees that children can carry out their rights and obligations. Understanding child protection in the broadest sense is all efforts that protect children to carry out their rights and obligations in a positive human way (Fitriani, 2016; S. C. Sirait, 2017; Sudrajat, 2011). Every child exercise their rights, this means that they are protected to obtain and maintain their right to live, they have survival, growth and protection and the implementation of their rights and obligations and can be protected. Legal protection for a child is any effort made consciously by any person or government agency, private sector that aims to strive for security, control and fulfillment of the 
welfare of life following existing human rights as regulated in Law Number 39 of 1999 concerning Human Rights.

Understanding legal protection for children can be interpreted as an effort to protect the law against fundamental rights and freedoms of children as well as various interests related to children's welfare (Rihardi, 2018; Rizky et al., 2019; Roza \& Arliman S, 2018). Child welfare is aligned with the aim of child protection to ensure the fulfillment of children's rights to live, grow, develop, and participate optimally by human dignity and to be protected from violence and discrimination, for the realization of quality, noble-minded Indonesian children and prosperous. As a guarantee for the fulfillment of children's rights optimally, children must receive full, comprehensive and comprehensive protection by referring to the basic principles of the 1989 Convention on the Rights of the Child. The principles are as follows (Rahayu, 2011):

1. Non-Discrimination, means the protection of all Indonesian children without distinguishing ethnicity, religion, race, gender, ethnicity, culture and language, legal status of children and physical or mental condition of children;

2. The best interests of the child This means that all actions involving children carried out by the government, the community, the legislative and judicial bodies, the best interests of the child must be the main consideration;

3. The right to life, survival and development This means that the basic rights of children must be protected by the state, government, society, family and parents; and

4. Appreciation of children's opinions, means respecting children's rights to participate and express their opinions in decision making, especially concerning children's lives.

\section{Protection and Fulfillment of Children's Rights in New Normal Era amid the Covid-19 Pandemic}

Since birth children have their rights as human beings, child protection is needed to ensure that their rights as human beings can be fulfilled. Under Article 4 of the Law on Child Protection states that every child has the right to live, grow, develop and participate appropriately following human dignity and dignity, and is protected from violence and discrimination. Every child has the right to a name as an identity and citizenship status. Every child has the right to worship according to their religion, thinking and expression according to the level of intelligence and age in the guidance of parents (Haling et al., 2018; Indriati et al., 2018).

All children have the right to know their parents, each child has the right to be raised and cared for by his parents (Said, 2018). Children also have the right to be cared for or adopted as foster children or adopted children by others following the provisions of the legislation in force if there is a reason for their parents can't guarantee the growth and development of children, or children in neglected circumstances. Every child has the right to get social security according to physical, mental, spiritual and social needs (Fauzi, 2020). 
Article 9 Number (1) on Child Protection Law states that every child has the right to receive education and teaching in the context of his personal development and level of intelligence according to his interests and talents. Specifically for children who have disabilities are also entitled to obtain special education, while for children who have excellence are also entitled to get special education. Every child has the right to express and be heard, accept, seek, and provide information following the level of intelligence and age for the development of themselves following the values of decency and propriety.

Article 11 on Child Protection Law states that every child has the right to rest and use his free time, to get along with children his age, play, play and be creative according to his interests, talents, and intelligence level for self-development. Article 12 of the Law concerning Child Protection states that every child with a disability has the right to receive rehabilitation, social assistance and maintenance of social welfare. The law further states that every child during the care of a parent, guardian or any other party responsible for care is entitled to protection from treatment, 1) discrimination; 2) exploitation, both economic and sexual; 3) neglect; 4) cruelty, violence and abuse; 5) injustice, and 6) other mistreatment.

Article 13 Number (2) on Child Protection Law states that, in the case of parents, guardians or caretakers of children taking all forms of treatment as referred to in Number (1), the offender is liable to a penalty. Article 14 Number (1) states that each child has the right to be cared for by his parents, unless there is a legal reason and/or legal rule indicating that the separation is in the best interest of the child and is the last consideration. Furthermore, Article 15 states that every child has the right to obtain protection from: 1) Abuse in political activities; 2) Involvement in armed disputes; 3) Involvement in social unrest; 4) Involvement in events that contain elements of violence; and 5) involvement in warfare; 6) Sexual crime.

Article 16 Number (1) on Child Protection Law states that every child has the right to obtain protection from targets of torture, torture or inhuman punishment. Number (2) states that every child has the right to obtain freedom following the law. Number (3) states that the arrest, detention, or crime of juvenile prison is only carried out if it is following applicable law and can only be done as a last resort.

Article 17 on Child Protection Law states that every child deprived of liberty has the right to receive humane treatment and placement is separated from adults; obtain legal assistance or other assistance effectively in each stage of applicable legal remedies; and defending themselves and obtaining justice before an objective and impartial juvenile court in a closed public hearing. In Number (2) it is stated that every child who is a victim or perpetrator of sexual violence or who is in conflict with the law has the right to be kept confidential. Article 18 states that every child who is a victim or criminal offense is entitled to legal assistance and other assistance.

Rahmitha P. Soendjojo and Irwanto, explained the children's rights to eight, namely (Kasran, 1981): 
1. Food Rights. At least children are given nutritious food 3 times a day, not just eating or junk food snacks only because parents do not want to bother cooking. Even in the womb, children are entitled to nutritious food. The most basic thing and must be known by parents that the best food for a baby is breast milk, for that a baby has the right to get it;

2. Health Service Rights. Children have the right to get priority in health services that are following standards, both in the form of immunization as a means of prevention or in the form of medication or healing;

3. Right to Education and Self-Development. The child has the right to attend school and if necessary the child is also entitled to attend activities at school, including additional tutoring. As parents must pay attention to the desires, interests, and talents of children in determining the school. Every child has the right to develop their potential and parents are obliged to support this. We are not only required to pay attention to gifted or gifted children but also children with special needs such as people with autism, the visually impaired, deaf, mentally disabled, or children with certain disorders and diseases;

4. Residence Rights. Children should get a decent place to live. However, it is very unfortunate at this time housing for the middle and lower classes is still relatively alarming, a cramped and dirty residence;

5. Clothing Rights. The child has the right to get proper clothing or clothing. Decent clothing does not have to be expensive and branded, but most importantly the clothes are clean and neat. Get used to also that children always wear clothes politely and appropriately;

6. Right to Protection Types of rights of children to get protection, namely physical, emotional, sexual, and neglect. Physical protection, never hit or abuse children. Tweaking and pinching on the grounds of upholding any discipline is not justified. Emotional protection, do not curse children, label them with negative titles, or other verbal expressions that are abusive. Especially in toddlers, children do not understand their behavior is not true in the eyes of adults. Sexual protection, don't treat a child's body like a toy item, even if it is done with a joke;

7. Play Rights Children have the right to play and enjoy their leisure time. Many children are employed as beggars so they don't have time to play and socialize with their peers. In fact, by playing, children can develop their creativity and potential; and

8. Right to Participate. This right is most often ignored by parents because they think that children do not know anything. Children should be introduced from childhood to their right to participate, from offering or providing food and clothing choices to the activities they want to do.

Based on the children's rights above, efforts to protect children's rights need to be carried out as early as possible, from the fetus in the womb to the eighteen-year-old child. Based on the concept of comprehensive child protection, the law lays down the obligation to provide protection to children based on the principles of non- 
discrimination, the best interests of the child, the rights to life, survival, and development, and the principle of respect for the views/opinions of children (Haliah, 2016; Rofiq et al., 2019).

In dealing with this new normal condition due to the Covid-19 pandemic, based on data from the National Task Force on June 2, 2020, the number of cases of Covid19 disease in children continues to increase. The percentage of children aged $0-17$ years who were exposed to Covid-19 reached 7.9 percent of the total 27,549 cases. The high number of cases at this time concerns the Ministry of Women's Empowerment and Child Protection. The Ministry of Women's Empowerment and Child Protection wants the state in the new normal era to guarantee the protection of children from Covid-19 transmission. Because there will be many changes that occur in the new normal era of life (Saputra, 2020).

One of the most important for the protection of children in the new normal era is the rules of health protocols that can be a guide for parents and caregivers of children. Examples of some things parents and caregivers who have had school-age children to pay attention to in the new normal era (Saputra, 2020). Like not taking off the mask while at school, keeping a distance, washing hands, only eating supplies from home, not sharing food with others, immediately changing clothes, and diligently washing hands (Anis, 2019). New normal policy strategies must also be accompanied by protocols that are implemented properly and consistently with regard to the interests of children. Child protection must be carried out everywhere, especially in education units. It is very important for the government, especially to talk about aspects of prevention so that in the new normal era, it is hoped that none of our children will have problems with the implementation of new normal in the education unit.

This legal protection will provide legal protection for the existence and rights of children: 1) Children as legal subjects Children are classified as beings who have human rights that are bound by laws and regulations, and 2) Equal rights and obligations of children a child will have the same rights and obligations as an adult in accordance with the provisions and legislation. Then, as for the external elements in the child are 1) The existence of legal provisions with the principle of equality in law (equality before the law); and 2) The existence of special rights (privileges) from the government through the 1945 Constitution.

Child protection can be divided into 2 (two) parts, i.e. 1) juridical child protection, which includes: protection in the field of public law and in the field of civil law; and 2) protection of non-juridical children, including protection in the social sector, health sector, education sector. According to Ahmad Kamil, Child Protection is the responsibility of parents, family, community, government, and the state which is a series of activities carried out continuously for the protection of children's rights (Kamil \& Fauzan, 2008). Extra supervision of the child both personally and as part of the community, needs to be done. It is intended to protect children's rights and prevent the entry of negative external influences that can interfere with child development 
(Umar \& Ma'ani, 2018). Child protection as per the terms of understanding stated in Article 1 number 2 on Child Protection Law can be realized if it has the support and responsibility of various parties. The support needed to realize the protection of children's rights in Indonesia is regulated in Article 20 on Child Protection Law which states that the state, government, regional government, community, family, and parents or guardians are obliged and responsible for the implementation of child protection.

The Ministry of Women's Empowerment and Child Protection wants the state in the new normal era to guarantee the protection of children from Covid-19 transmission. Therefore, the State and the government are also obliged and responsible to provide support for facilities and infrastructure in the implementation of child protection. Regulations regarding the obligations and responsibilities of the state and government are listed in the provisions of Article 21 and Article 22 on Child Protection Law.

Article 23 and Article 24 on the Child Protection Law regulates state and government guarantees for the implementation of child protection. The state and government guarantee the protection, care and welfare of children by taking into account the rights and obligations of parents, guardians, or other people who are legally responsible for children. The state and the government also guarantee children to exercise their right to express their opinions according to the age and intelligence level of the child. The guarantees given by the state and government are also followed by supervision in the implementation of child protection. The community's obligations and responsibilities for child protection as regulated in Article 25 on Child Protection Law.

The community's obligations and responsibilities towards protecting children are carried out through activities that involve the community in the implementation of child protection. The provision of Article 72 paragraph (2) on Child Protection Law states that the role of the community is carried out by individuals, child protection institutions, social institutions, non-governmental organizations, educational institutions, religious institutions, business entities, and mass media. Article 26 on Child Protection Law regulates the obligations and responsibilities of family and parents. Parents have the obligation and responsibility to: 1) take care of, care for, educate and protect their children; 2) to develop children according to their abilities, interests and interests; 3) prevent marriages at the age of children; and 4) provide character education and character building for children.

The implementation of child protection based on Child Protection Law is held in the areas of religion, health, education, social, and special protection for children listed in Article 59 number 2 of the Law on Child Protection. The state as the highest and most powerful organization also has a big role in protecting the rights of children which is realized by issuing regulations regarding the granting of protection for children so that there are legal guarantees for child protection activities which will later impact on the continuity of child protection activities and prevent abuse in the implementation of child protection. The child protection measures carried out by the 
government are part of the state's goal, namely to protect the nation and the state and for the sake of public welfare.

With the implementation of the new normal policy, the role of parents is very important and has a greater share in protecting children, because parents must remind their children about the health protocol, there must be a substance that is embedded in the care of children (Khair, 2020; Sudrajat, 2011). Parents must also be able to guide their children if they experience psychological disorders, but the community also plays a role in protecting the rights of children in the midst of entering this new normal era. Community participation can be realized while maintaining the rights of children when they are outside the home environment so that they will still feel comfortable outside the home. The elements of society involved in protecting children are not only individuals but also involve community organizations, Non-Governmental Organizations, Child Protection Commissions, other organizations that have a concern for child protection (Haling et al., 2018; Indriati et al., 2018).

\section{Implementation of Policies against the Protection of Children's Rights in New Normal Era during Covid-19 Pandemic}

The adoption of the new normal era policy amid the Covid-19 pandemic, requires parents and families in Indonesia to provide care for children that is adapted to changing conditions today. Since children are the most vulnerable creatures, we must protect them and the role of care is very important. It aims to protect millions of Indonesian children that must be done by parents, family or substitute caregivers. Protecting children is our shared duty, not only parents and families, all adults are also obliged to fulfill the rights of children (S. C. Sirait, 2017).

The application of childcare, both in the period before the pandemic, during the pandemic or the new normal, must be based on child protection which includes the fulfillment of children's rights and special protection of children. Also, applying 4 (four) principles of child protection, namely non-discrimination, the best interests of children, life, growth and development, and participation. Child rights-based care aims to meet the needs for affection, attachment, safety and well-being that is permanent and sustainable, in the best interests of the child. As for the pattern of childcare in the era of the new normal must be adjusted back to the existing conditions. Parents who were previously caretakers as well as teacher assistants, and children's talk partners for 24 hours, must re-adjust to the changes that occur. For this reason, the Ministry of Women's Empowerment and Child Protection is preparing guidelines for child rightsbased care, both in families and in substitute care institutions to be implemented in the new normal era.

The Child Protection Law states that child protection aims to ensure the fulfillment of children's rights so that they can live, grow, develop and participate optimally following human dignity and dignity, and receive protection from violence and discrimination for the realization of quality Indonesian children, noble and prosperous. Children's rights in the Human Rights Law are regulated in the provisions 
of Article 52 through Article 66. The Human Rights Law does not include detailed provisions regarding children's obligations. Provisions regarding the obligations contained in the Act are basic human obligations as a whole. The Child Protection Law regulates the rights and obligations of children. Children's rights are regulated in the provisions of Article 4 through Article 18. The children's rights listed in on Child Protection Law include the rights to:

1. The right to be able to live, grow, develop and participate appropriately following human dignity and dignity and get protection from violence and discrimination;

2. The right to a name as an identity and citizenship status;

3. The right to worship according to his religion, think and create according to the level of intelligence and age in the guidance of parents;

4. The right to know his parents, raised and cared for by his parents;

5. The right to obtain health services and social security following physical, mental, spiritual and social needs;

6. The right to education and teaching in the context of personal development and the level of intelligence according to their interests and talents;

7. The right to obtain special education, rehabilitation, social assistance and maintenance of social welfare for children with disabilities;

8. The right to obtain special education for children who have excellence;

9. The right to express and be heard, accept, seek and provide information following the level of intelligence and age for the development of himself following the values of decency and propriety;

10. The right to rest and take advantage of free time, associating with children the same age, playing, recreation and creative following their interests, talents and intelligence level for self-development;

11. The right to be protected from discrimination, exploitation (both economic and sexual), neglect, cruelty, violence, mistreatment, injustice, and another mistreatment;

12. The right to be cared for by his parents unless there is a legal reason and/or legal rule showing that the separation is in the best interest of the child and is a final consideration;

13. The right to protection from the targets of inhumane torture, torture or sentence;

14. The right to freedom following the law;

15. The right to obtain humane treatment and placement separated from adults, obtain legal assistance or other assistance effectively in each stage of applicable legal remedies, as well as defend themselves and obtain justice before an objective and impartial Juvenile Court in closed hearings for general, for every child deprived of liberty;

16. The right to be kept confidential, for every child who is a victim or perpetrator of sexual violence or who is dealing with the law; and

17. The right to get legal assistance and other assistance, for every child who is a victim or a criminal. 
Provisions containing provisions regarding the rights of children in the Law on Child Protection have many similarities with the provisions of children's rights in the Law on Human Rights. The Law on Child Protection also regulates the obligations that must be carried out by each child. The regulation of rights exists in several laws of the Republic of Indonesia, the State guarantees and must fulfill the basic rights of children which include the right to life, growth and development rights, protection rights, participation rights (Fitriani, 2016).

So efforts to strengthen child rights-based care of children, starting from parents and families during the pandemic. Concerning the stipulation of policies on the schedule for children to go to school during the new normal era during Covid-19 pandemic, the Ministry of Women's Empowerment and Child Protection has provided input to the relevant Ministries including the Task Force for the Acceleration of Handling Covid-19. The most important key that we convey is that from the aspect of health and safety for children, this is their primary right (Sudrajat, 2011).

The Ministry of Women's Empowerment and Child Protection has sought to improve child rights-based care, namely by developing a Family Learning Center or Pusat Pembelajaran Keluarga (PUSPAGA) involving psychologists and counselors to provide counseling, education and information assistance to families free of charge. This PUSPAGA service operates under the coordination of the Office of Women's Empowerment and Child Protection in the Province and District/City. Amid this pandemic, the role of PUSPAGA is very much needed by the community. For this reason, each region must improve PUSPAGA services as a provider of counseling, education and information services for families throughout Indonesia. At least in each province and district/city must have 1 (one) PUSPAGA, considering that all families need these services (KemenPPPA, 2020).

As for things that parents should be reminded of when at school during the new normal era, including not taking off their masks while at school, keeping their distance during public transportation, not holding objects in the vehicle, washing their hands immediately when arriving at their destination, keeping their distance with teachers, friends, and other school members, only eating supplies from home, not sharing food with others, immediately changing clothes when they get home, and diligently washing hands with soap. To achieve Indonesia Eligible Children (Indonesia Layak Anak/ IDOLA) 2030, parenting must refer to all children's rights that must be fulfilled. To realize this, of course the government cannot run alone, it needs support from crosscutting scientific sectors, not only psychology but also educators and education staff, health workers, in essence all must work together to make IDOLA in 2030 (Saputra, 2020).

In caring for children in the new normal era, parents must remain focused on fulfilling children's rights and forming positive characters in children. This must be applied by all means and methods such as creating care with love through smiles, without violence so that children grow full of love for people in their environment (Saputra, 2020). Some things parents can do to strengthen the psychological side of 
children, namely by practicing so that children imitating self-control and emotions, increasing self-confidence when dealing with others, strengthening commitment, continuing to learn and develop self-abilities, and the importance of strengthening selfregulation (KemenPPPA, 2020).

One example is the policy of implementing a new situation in the education unit, the Ministry of Women's Empowerment and Child Protection, which is the "Implementation Strategy of the Education Unit Opening Policy in the New Normal Order System" by involving the relevant ministries/institutions via virtual. The aim is to obtain input for the drafting of an education delivery protocol in the new normal, taking into account aspects of the fulfillment and protection of children's rights. The Ministry of Women's Empowerment and Protection is obliged to coordinate child protection in the fulfillment of children's rights and special protection, including in the current situation of the Covid-19 pandemic. Also, one of the reasons for this coordination was carried out because questions arose in the community about the certainty of the discourse of the reopening of schools, madrasas and boarding schools. Technical protocols need to be prepared and communicated to all parties so that together they can mitigate the risks that may arise (KemenPPPA, 2020).

If this new normal policy strategy must be accompanied by a variety of new normal protocols that can be implemented appropriately and consistently with due regard to the best interests of the child. Child protection must be carried out wherever children are, including when in the education unit. It is very important for the government, especially to discuss aspects of prevention, so that in the new normal era, it is hoped that none of our children will have problems with the implementation of new normal in the education unit. On the other hand, the Covid-19 Task Force of the Indonesian Pediatrician Association (IDAI) believes that children have the right to life, healthy rights as well as education rights, but what must be the main focus at this time is the right of children to live. During the transition to new normal, each Head of the Education Office and the Head of the Education Unit in the region together with the Regional Task Force must carry out the mapping of regional readiness according to the criteria and checklist that is being prepared (KemenPPPA, 2020).

The Indonesian Ministry of Women's Empowerment and Child Protection optimizes child protection efforts in the Covid-19 pandemic that is embodied through community based Integrated child Protection or PATBM. PATBM is a movement of groups or networks of citizens at a community level that works in a coordinated form for the realization of child protection efforts (Krisnawati, 2020). In line with the mandate of the Child Protection Law, the child is entitled to the protection of life, growth, and growth. Children as the successor generation of the nation's ideals must be protected from any form of inhumane treatment that affects human rights. According to Law number 23 of 2012 article 1, the child is a person who has not stepped on 18 years, including a child who is still in the womb. KPPA has made several efforts in particular to protect children in Indonesia. One of the efforts made by the Indonesian Ministry of Women's Empowerment and Child Protection is to provide decent information of the child. 
Indonesian Ministry of Women's Empowerment and Child Protection performs forms of child protection PATBM during the COVID-19 pandemic through the prevention of child abuse and response to child violence. Here's an explanation (Krisnawati, 2020):

1. Prevention of child abuse. This effort was made to: 1) changes in norms or understandings that do not support, by socializing the positive norms of nonviolence; 2) Realization of a safe relationship to prevent violence, by establishing community or family level of support and control systems, in order to realize parenting; 3) The increase in life skills and child resilience in preventing violence; and

2. Response to child violence this effort is done for the sake of effective mechanisms in order to dedate, help, and protect the children of violent victims. Thus, children of violent victims and perpetrators of children can achieve justice. Goal: 1) The sensitivity of the community in knowing children's victims of violence. 2) There is a service for the acceptance of accessible reports that can help the victim's child to get assistance immediately. 3) The existence of networking with various service institutions that are quality and easily accessible so that victims and perpetrators, can handle children in the risk of violence.

At the time of the Covid-19 pandemic, there is a grammar that can be done when working with children, namely (Krisnawati, 2020): 1) diligent and patient, behave agreeable to work with the child; 2) Respect and cherish the child's view for the best for the child; 3) The identity of the child in the observation, the child in supervision patients and children positive Covid-19; 4) The identity of the child in the observation, the child in supervision patients and the child positive Covid-19 must be kept confidential; 5) In the local culture must be dressed, communicated, and behave politely according to the prevailing norms; 6) Children who are currently on psychological recovery and other basic needs must be supported; 7) Dignity and child self-esteem must be respected; and sensitive to special needs for children with disabilities. Meanwhile, not to be done: 1). do not commit violence, exploitation, abandonment and other mistreatment; 2) not letting children in vulnerable situations be exploited; 3) Something meaningful sexual means should not be recommended; 4) Assistance in unaccompanied minors, such as family or parents in any place and condition; and 5) utilize any media to share the identity of a child's photo, or video.

\section{CONCLUSION}

Child protection in fulfilling their rights in new normal era situations is the responsibility of parents, family, community, local government, government and state which is a series of activities carried out continuously for the protection of children's rights especially the right to safety and health, as the organizer of protection child. In its simplest form, child protection strives so that every child's right is not harmed. Child protection is complementary to other rights ensuring that children will receive 
what they need so that they can survive, develop and grow in the best interests of the child.

Child protection must be carried out wherever children are, including when in the education unit. It is very important for the government, especially to discuss aspects of prevention, so that in the new normal era, it is hoped that none of our children will have problems with the implementation of new normal era in various fields. Organizers of child protection must be able to deal with issues of maximizing the rights of children and all child protection providers rise together to build a better Indonesia in the future.

\section{REFERENCES}

Anindia, I. A. (2019). PERLINDUNGAN HUKUM TERHADAP PERDAGANGAN ANAK DENGAN MODUS PERNIKAHAN DALAM PERSPEKTIF VIKTIMOLOGIS. Litigasi, 19(1), 89-115. https://doi.org/doi.org/10.23969/litigasi.v19i1.776

Anis, M. (2019). PERLINDUNGAN ANAK TERHADAP KEKERASAN SEKSUAL DI KOTA MAKASSAR. El-Iqthisadi: Jurusan Hukum Ekonomi Syariah Fakultas Syariah Dan Hukum, 1(2), 37-44.

Arliman.S, L. (2016). PERLINDUNGAN HUKUM TERHADAP ANAK YANG TEREKSPLOITASI SECARA EKONOMI DI KOTA PADANG. Arena Hukum, 9(1), 73-93. https:// doi.org/10.21776/ub.arenahukum.2016.00901.5

Azkia, Z., \& Is, M. S. (2018). Perlindungan Hukum Terhadap Hak Asasi Anak Yang Menjadi Korban Kekerasan. Nurani: Jurnal Kajian Syari'ah Dan Masyarakat, 18(1), 151-162. https://doi.org/10.19109/nurani.v18i1.1904

Disemadi, H. S. (2019). ADULTERY CHILD STATUS IN ISLAMIC LAW AND

IN THE CIVIL CODE. Legal Standing : Jurnal Imu Hukum, 3(2), 20-31. https://doi.org/10.24269/ls.v3i2.1877

Disemadi, H. S., \& Shaleh, A. I. (2020). Banking credit restructuring policy amid COVID-19 pandemic in Indonesia. Jurnal Inovasi Ekonomi, 3(3). https://doi.org/https://doi.org/10.22219/jiko.v5i3.11790

Erdianti, R. N., \& Al-Fatih, S. (2019). Fostering as an Alternative Sanction for Juveniles in the Perspective of Child Protection in Indonesia. JILS Journal of Indonesian Legal Studies), 4(1), 119-128. https://doi.org/10.15294/JILS.V4I01.29315

Fauzi, R. (2020). Upaya Penanggulangan Tindak Pidana Pencabulan Terhadap Anak di Kota Padang. KERTHA WICAKS ANA: Sarana Komunikasi Dosen Dan Mahasiswa, 14(1), 1-8. https://doi.org/doi.org/10.22225/kw.14.1.1529.1-8

Filler, E. (1995). Children in Trouble United Nations Expact Group Meeting Austrian Federal Ministry for Youth and Family.

Fitriani, R. (2016). Peranan Penyelenggara Perlindungan Anak Dalam Melindungi 
Dan Memenuhi Hak-Hak Anak. Jurnal Hukum Samudra Keadilan, 11(2), 250-358.

Fitriyana, N. (2020). GOD SPOT DAN TATANAN NEW NORMAL DI

TENGAH PANDEMI COVID-19. Jurnal Ilmu Agama: Mengkaji Doktrin,

Pemikiran, Dan Fenomena Agama, 21(1), 1-24.

https://doi.org/doi.org/10.19109/jia.v21i1.6147

Gosita, A. (1999). Masalah Perlindungan Anak. Akademindo.

Haliah, D. (2016). Nikah Sirri dan Perlindungan Hak-hak Wanita dan Anak (Analisis dan Solusi dalam Bingkai Syariah). Al-Abkam: Jurnal Ilmu Syari'ab Dan Hukum, $1(1), 35-50$.

Haling, S., Halim, P., Badruddin, S., \& Djanggih, H. (2018). PERLINDUNGAN HAK ASASI ANAK JALANAN DALAM BIDANG PENDIDIKAN MENURUT HUKUM NASIONAL DAN KONVENSI INTERNASIONAL. Jurnal Hukum \& Pembangunan, 48(2), 361. https://doi.org/10.21143/jhp.vol48.no2.1668

Hariyadi, \& Arliman S, L. (2018). PERAN ORANGTUA DALAM MENGAWASI ANAK DALAM MENGAKSES MEDIA INTERNET UNTUK MEWUJUDKAN PERLINDUNGAN HAK ANAK. Soumatera Law Review, 1(2), 267-281. https://doi.org/10.22216/soumlaw.v1i2.3716

Hidayati, N. (2014). Perlindungan Anak terhadap Kejahatan Kekerasan Seksual (Pedofilia). Ragam Jurnal Pengembangan Humaniora, 14(1), 68-73.

Indriati, N. Y., Wahyuningsih, K. K., Sanyoto, \& Suyadi. (2018). PERLINDUNGAN DAN PEMENUHAN HAK ANAK (Studi Tentang Orangtua Sebagai Buruh Migran Di Kabupaten Banyumas). Mimbar Hukum - Fakultas Hukum Universitas Gadjah Mada, 29(3), 474-487. https://doi.org/10.22146/jmh.24315

Istiqomah, L. D., Jaya, N. S. P., \& Aryadi, D. (2019). CRIMINAL THREATS FOR PERPETRATORS OF OMISSION IN CHILD ABUSE IN INDONESIA. 6(3), 406-417. https://doi.org/doi.org/10.26532/jph.v6i3.10945

Juliana, R., \& Arifin, R. (2019). Anak dan Kejahatan (Faktor Penyebab dan Perlindungan Hukum). Jurnal Selat, 6(2), 225-234. https://doi.org/10.31629/selat.v6i2.1019

Kamil, A., \& Fauzan. (2008). Hukum Perlindungan dan Pengangkatan Anak di Indonesia. PT RajaGrafindo Persada.

Kasran, S. (1981). Mental Sehat Pembinaan Anak, Remaja, dan Orang Tua. PT. Rakan Incorp.

KemenPPPA. (2020). New Normal di Satuan Pendidikan Harus Utamakan Anak.

Khair, U. (2020). PELAKSANAAN HAK ASUH ANAK SETELAH TERJADINYA PERCERAIAN. JCH (Jurnal Cendekia Hukum), 5(2), 291-306. https://doi.org/10.33760/jch.v5i2.231 
Krisnawati, E. (2020). Panduan Perlindungan Anak PATBM saat Pandemi COVID-19 dari KPPPA.

Lasmadi, S., Wahyuningrum, K. S., \& Disemadi, H. S. (2020). KEBIJAKAN PERBAIKAN NORMA DALAM MENJANGKAU BATASAN MINIMAL UMUR PERKAWINAN. Gorontalo Law Review, 3(1), 1-16. https://doi.org/10.32662/golrev.v3i1.846

Muhyiddin. (2020). Covid-19, New Normal, dan Perencanaan Pembangunan di Indonesia. Jurnal Perencanaan Pembangunan: The Indonesian Journal of Development Planning, 4(2), 240-252. https://doi.org/10.36574/jpp.v4i2.118

Novika, G. D., Disemadi, H. S., \& Rochaeti, N. (2020). Legal protection in restitution to the victims of human trafficking. Legality: Jurnal Ilmiah Hukum, 28(1), 36-46. https://doi.org/10.22219/ljih.v28i1.10374

Peter Mahmud Marzuki. (2014). Penelitian Hukum. Kencana Prenada Media Group.

Purnamasari, S., Kusworo, K., \& Rahayu, P. Y. (2019). Upaya Pencegahan Kekerasan Terhadap Anak dan Perempuan dalam Menciptakan Lingkungan Ramah Keluarga. Jurnal Loyalitas Sosial: Journal of Community Service in Humanities and Social Sciences, 1(2), 71-81. https://doi.org/doi.org/10.32493/jls.v1i2.y2019.p71-81

Rahayu, D. (2011). Perlindungan Hukum bagi Buruh Migran Terhadap Tindakan Perdagangan Perempuan. Jurnal Hukum IUS QULA IUSTUM, 18(1), 115-136. https://doi.org/doi.org/10.20885/iustum.vol18.iss1.art7

Rihardi, S. A. (2018). PERLINDUNGAN HUKUM TERHADAP HAK-HAK ANAK PEREMPUAN SEBAGAI KORBAN EKSPLOITASI SEKSUAL. Literasi Hukum, 2(1), 61-72.

Rizky, M. N., Fitriani, R. I., Sudibyo, M. W., Husnasari, F. A., \& Maulana, F. (2019). Perlindungan Hukum Terhadap Anak Korban Eksploitasi Seksual Komersial Melalui Media Sosial. Media Iuris, 2(2), 197-216. https://doi.org/10.20473/mi.v2i2.13193

Rofiq, A., Disemadi, H. S., \& Jaya, N. S. P. (2019). Criminal Objectives Integrality in the Indonesian Criminal Justice System. Al-Risalah, 19(2), 179-190. https://doi.org/10.30631/al-risalah.v19i2.458

Roza, D., \& Arliman S, L. (2018). Peran Pemerintah Daerah Di Dalam Melindungi Hak Anak Di Indonesia. Masalah-Masalah Hukum, 47(1), 10-21. https://doi.org/10.14710/mmh.47.1.2018.10-21

Said, M. F. (2018). PERLINDUNGAN HUKUM TERHADAP ANAK DALAM PERSPEKTIF HAK ASASI MANUSIA. JCH (Jurnal Cendekia Hukum), 4(1), 141-151. https://doi.org/10.33760/jch.v4i1.97

Saputra, M. G. (2020). KemenPPP A Minta Kebijakan New Normal Perhatikan Perlindungan Anak. 
Setiawan, S., Saifunuha, M. A., Kautsar, J. L., \& Wulandari, C. (2019). Community Empowerment on Establishment of Friendly-Village for Women and Children. Indonesian Journal of Advocacy and Legal Services, 1(1), 5-22. https://doi.org/10.15294/ijals.v1i1.33756

Setyaningrum, A., \& Arifin, R. (2019). Analisis Upaya Perlindungan dan Pemulihan Terhadap Korban Kekerasan dalam Rumah Tangga (KDRT) Khususnya AnakAnak dan Perempuan. JURN AL MUQODDIMAH : Jurnal Ilmu Sosial, Politik Dan Hummaniora, 3(1), 9-19. https://doi.org/10.31604/jim.v3i1.2019.9-19

Sholihah, H. (2018). PERLINDUNGAN ANAK DALAM PERSPEKTIF HUKUM ISLAM. Al-Afkar, Journal For Islamic Studies, 1(1), 38-56. https://doi.org/doi.org/10.31943/afkar_journal.v1i1.3

Sirait, A. M. (2018). Eksploitasi Seksual Komersial Mengintai Anak Kita. Jurnal Legislasi Indonesia, 5(3), 87-92.

Sirait, S. C. (2017). TANGGUNG JAWAB PEMERINTAH UNTUK MEMBERIKAN PENDIDIKAN KEPADA ANAK TERLANTAR DALAM PERSPEKTIF UNDANG-UNDANG PERLINDUNGAN ANAK. De Lega Lata, 2(1), 158-182. https://doi.org/doi.org/10.30596/dll.v2i1.1146

Sudrajat, T. (2011). Perlindungan Hukum terhadap Hak Anak sebagai Hak Asasi Manusia dalam Perspektif Sistem Hukum Keluarga di Indonesia. Kanun: Jurnal Ilmu Hukum, 3(2), 111-132.

Umar, M. H., \& Ma'ani, B. (2018). Urgensi Hak dan Perlindungan Anak dalam Perspektif Maqashid Al-Syariah. Al-Risalah, 17(2), 201-212. https://doi.org/10.30631/al-risalah.v17i02.64

Wahyuni, I. (2015). PERMASALAHAN PEKERJA ANAK: PERSPEKTIF MAQASHID SYARI'AH. Mabkamab: Jurnal Kajian Hukum Islam, 9(1), 84-97. https://doi.org/10.24235/mahkamah.v9i1.292

Wati, D. E., \& Puspitasari, I. (2018). Kekerasan Terhadap Anak, Penanaman Disiplin, dan Regulasi Emosi Orang Tua. Jurnal VARIDIKA, 30(1), 21-26. https://doi.org/10.23917/varidika.v30i1.6541

Windari, R. (2019). Penanggulangan Eksploitasi Seksual Komersial Anak (ESKA) Berdasarkan Global - Local Based Approach (Glocalization). Soumatera Law Review, 2(2), 282-296. https://doi.org/10.22216/soumlaw.v2i2.4369 